\title{
Predominance of HBsAg (+ve) and Anti-HCV Positivity among Blood Donors: Experience in a Private Hospital of Dhaka, Bangladesh
}

Moyen Uddin Pk $^{1}$ and Abu Mohammad Azmal Morshed ${ }^{2 *}$

${ }^{1}$ Depatrment of Biochemistry, Primeasia University, Banani, Dhaka-1213, Bangladesh

${ }^{2}$ Depatrment of Chemistry, Primeasia University, Banani, Dhaka-1213, Bangladesh

\begin{abstract}
Background: Hepatitis $B$ and $C$ virus infection in Bangladesh continues to be a public health problem for the last few decades. Transfusion related hepatitis is a major concern among the transfusion medicine community in Bangladesh.
\end{abstract}

Objectives: This study was conceded out to characterize the security profile of Bangladeshi healthy blood donors and to point out the importance of screenings programs that must be applied, and also patterns of virus positivity among different age \& sex groups were determined.

Patients and methods: Through out this study we reviewed the testing records of 3048 healthy blood donors (Male-2680 and Female-368) who presented by random at blood bank's records from January $1^{\text {st }}, 2010$ to December $31^{\text {st }}, 2010$ at a private Hospital in Dhaka, Bangladesh. All the samples were examined using $3^{\text {rd }}$ generation enzyme linked immunosorbant assays for Anti-HCV and HBsAg (+ve) detection. Statistical Analysis was done using standard procedure.

Results: The study found the overall predominance of HBsAg (+ve) was $1.24 \%$ and Anti-HCV was $0.17 \%$. Predominance of co-infection with HBV and HCV was $0.00 \%$.

Conclusions: Impact of this paper will help to provide information on the current risks of blood transfusion in Bangladesh thus to advice of alternatives to transfusion can mitigate some of those concerns now and near future.

Keywords: HBsAg(+ve); Anti-HCV; Anti-HIV; Virus; Co-infections

\section{Background}

Hepatitis has become an issue of global importance for its alarming appearance in the global health problem. Most of the blood collected for transfusion in Bangladesh is collected mainly from the community blood centers; approximately one-half of these centers are maintained by the different local and international blood collecting agencies, whereas the rest are run by other nonprofit self service community agencies.

Hepatitis B virus a member of the Hepadnavirus family transmitted via blood transfusion, I.V. drug abuse, during intercourse and parentally from mother to newborn. Hepatitis B infection is the most common infectious diseases in the earth and a major public health crisis. It has been predictable that 350 million people through the world are persistent hepatitis B Virus (HBs) carriers [1]. Also, blood transfusion strikingly raises the incidence of Anti-HCV reactivity. Co-infection by Hepatotropic viruses is not uncommon because of the fact that Hepatitis $B$ virus and $C$ virus share analogous routes of transmission. The relative role of the infecting viruses in determining the concluding clinical picture is not yet well defined. Several reports indicate that clinical and pathological severity of liver disease among co-infected patients is high and in case of Hepatocellular Carcinoma (HCC), co-occurrence of both viruses is a common phenomenon [2]. The predominance of different virus infection among North American population show wide regional variation, according to the previous findings the overall predominance of Anti-HCV was $1.8 \%$. A survey showed a predominance of hepatitis B virus to be $6.6 \%$ for the core antigen in Mexico [3]. A community-based study conducted that $13 \%$ people were $\operatorname{HBs} A g(+v e)$ and $17 \%$ were positive for Anti-HCV in Taiwan [4]. The Predominance of hepatitis C antibodies was $0.28 \%$ in healthcare workers in a study area depended on rural areas of Scotland [5].
In Bangladesh, the predominance of $\mathrm{HBsAg}(+\mathrm{ve})$ cases are about $8 \%$ among the intravenous drug users [6], 9.7\% in commercial sex workers [7] and also 5.9\% in truck drivers. However that of Anti-HCV a predominance of less than $1 \%$ in truck drivers reported formerly [8-10]. Only a very few studies has been studied so far in Bangladesh to determine the predominance rate of Hepatotropic virus infection among healthy blood donors. Through the study it was determined the predominance of Hepatitis B \& C infections among the healthy blood donors at a private hospital in Bangladesh.

\section{Objectives}

Hepatitis B continues to represent a serious challenge in Bangladesh with the increasing predominance among healthy blood donors. The results of this study tinted the high predominance and correlates of HBsAg(+ve) in Bangladesh. The high predominance underscores the need for preventive measures against hepatitis B virus infection among women. This paper has attempted to provide information on the current risks of blood transfusion in Bangladesh thus to advise of alternatives to transfusion can mitigate some of those concerns now and in the future.

*Corresponding author: AM Azmal Morshed, Department of Chemistry, Primeasia University, Kamal Ataturk Avenue, Banani, Dhaka-1213, Bangladesh Tel: +88-01816487617; E-mail: azmal.morshed@primeasia.edu.bd

Received June 12, 2013; Accepted August 23, 2013; Published August 25, 2013

Citation: Uddin MP, Azmal Morshed AM (2013) Predominance of HBsAg (+ve) and Anti-HCV Positivity among Blood Donors: Experience in a Private Hospital of Dhaka, Bangladesh. J Blood Disorders Transf 4: 154. doi: 10.4172/21559864.1000154

Copyright: @ 2013 Uddin MP, et al. This is an open-access article distributed under the terms of the Creative Commons Attribution License, which permits unrestricted use, distribution, and reproduction in any medium, provided the original author and source are credited. 
Citation: Uddin MP, Azmal Morshed AM (2013) Predominance of HBsAg (+ve) and Anti-HCV Positivity among Blood Donors: Experience in a Private Hospital of Dhaka, Bangladesh. J Blood Disorders Transf 4: 154. doi: 10.4172/2155-9864.1000154

\section{Patients and Methods}

\section{Study population}

A total number of 3048 healthy blood donors were screened for HBsAg (2680 male \& 368 female) and a total number of 3010 (2779 male \& 231 female) healthy donors were screened for Anti-HCV.

\section{Sample collection}

This is a retrospective study we reviewed the testing records of 3048 donors who presented at random at a blood Bank as well as the blood drives conducted between January $1^{\text {st }}, 2010$ to December $31^{\text {st }}$, 2010 at Anwer Khan Modern Medical College \& Hospital Ltd, Dhaka, Bangladesh. Blood donor's data and results of HBsAg (+ve) and AntiHCV were retrieved using the blood banks records of donors.

\section{Serological test}

All the samples were examined using $3^{\text {rd }}$ generation enzyme linked immunosorbant assays (ELISA Innogenetics, Belgium) for Anti-HCV and HBsAg detection.

\section{Statistical Analysis}

Statistical analysis was done on all variables to obtain a frequency distribution. Quantitative variables were reported with range, frequency and percentage. Proportions were analyzed with chi-square test. $\mathrm{P}$ value of 0.05 or less was considered as statistically significant at $95 \%$ confidence interval. Data were analyzed using Graph Pad 5 Prism.

\section{Results}

\section{Characteristics of study groups}

During the surveillance through one year duration mentioned, a total number of 3048 healthy blood donor were screened for HBsAg (2680, 87.92\% male \& $368,12.08 \%$ female) and a total number of $3010(2779,92.32 \%$ male \& 231, 7.68\% female) healthy donors were screened for Anti-HCV.

\section{Distribution of infectivity by sex and age groups}

A total number of $3010(2779,92.32 \%$ male $\& 231,7.68 \%)$ healthy donors were screened for Anti-HCV. Among those screened for HBsAg (3048), positive results for HBsAg (+ve) was found on only on 38 (1.24\%) people of the total (male 29, $1.08 \%$ and female 9, 2.44\%) donors, yielding a predominance of $1.24 \%$ of total. Statistically, there was no significant difference on the predominance of $\mathrm{HBsAg}(+\mathrm{ve})$ for gender difference. But in case of anti- HCV there were only 5 donors who tested positive, with a predominance rate of $0.17 \%$ of total tested. The predominance of anti-HCV between males and females were $0.17 \%$ and $0.00 \%$, respectively (Table 1 ; Figures 1 and 2 ).

\section{Proportional statements of infection by Anti-HCV, HBsAg}

Stratification according to age groups was done using the following

\begin{tabular}{|c|c|c|c|c|c|c|}
\hline \multirow{2}{*}{$\begin{array}{l}\text { Group } \\
\text { (Sex) }\end{array}$} & \multicolumn{2}{|c|}{ HBsAg } & \multirow[b]{2}{*}{$\begin{array}{c}\text { Chi-Square } \\
\text { Test }\end{array}$} & \multirow[b]{2}{*}{\begin{tabular}{|l|} 
Patient's \\
Number
\end{tabular}} & \multicolumn{2}{|c|}{ Anti-HCV } \\
\hline & $\begin{array}{l}\text { Patient's } \\
\text { Number }\end{array}$ & Positive & & & $\begin{array}{l}\text { Positive } \\
\text { Case }\end{array}$ & $\begin{array}{c}\text { Chi-Square } \\
\text { Test }\end{array}$ \\
\hline Male & 2680 & $29(1.08 \%)$ & \multirow{3}{*}{$\begin{array}{c}0.0545 \\
\text { NS } \\
\text { Male } \\
\text { vs } \\
\text { Female }\end{array}$} & 2779 & $5(0.17 \%)$ & \multirow{3}{*}{$\begin{array}{c}0.2596 \\
\text { NS } \\
\text { Male } \\
\text { vs Female }\end{array}$} \\
\hline Female & 368 & 09 (2.44\%) & & 231 & 0 & \\
\hline Total & 3048 & 38 (1.24\%) & & 3010 & $5(0.17 \%)$ & \\
\hline
\end{tabular}

Significance $(\mathrm{S})=\mathrm{P}<0.05$

Table 1: Frequency of $\mathrm{HBsAg}(+\mathrm{ve})$ and anti-HCV among blood donors according to gender.

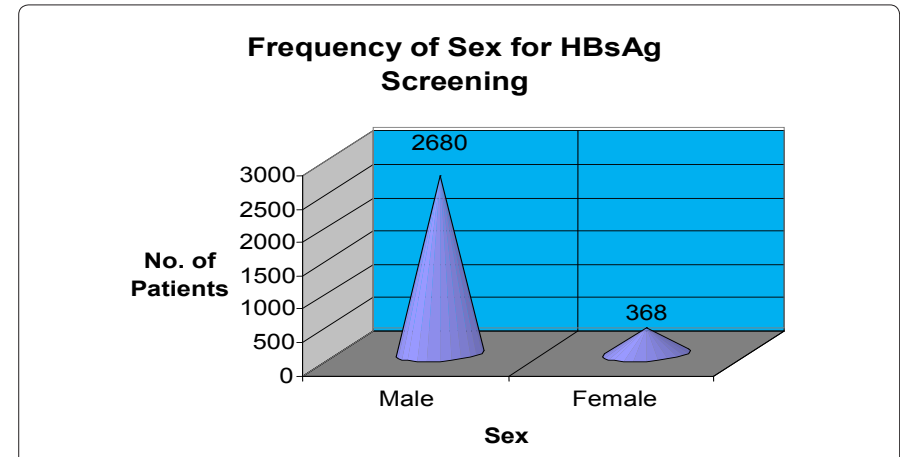

Abbreviations: $\mathrm{HBsAg}(+\mathrm{ve})$, hepatitis B surface antigen

Figure 1: Frequency of $\mathrm{HBsAg}(+\mathrm{ve})$ according to Sex group.

\section{Frequency of sex for Anti-HCV Screening}

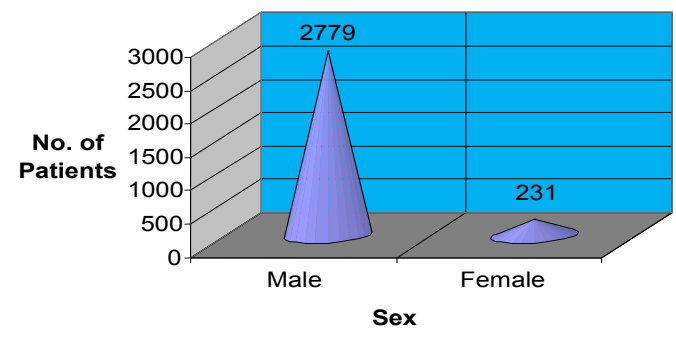

Abbreviations: Anti-HCV, hepatitis $\mathrm{C}$ virus antibody

Figure 2: Frequency of Anti-HCV according to Sex group.

age limits: 18-28(A), 29-39(B), 40-50(C) years and above 50 years (D). Among the groups, majority of the donors tested for HBsAg on ages groups- A, B, C \& D is 1761 ( $57.77 \%)$, $631(20.70 \%)$, $592(19.42 \%)$ and $64(2.09 \%)$ donors correspondingly (Table 2 and Figure 3$)$. This trend is also similar among those tested for anti-HCV with values of 2166 (71.96\%) for ages- A, 492 (16.34\%) for B, 329 (10.93\%) for C, and 23(0.76\%) for ages-D. The predominance of HBsAg (+ve) along with the age groups were $0.62 \%$ for A , $2.69 \%$ for B , $1.01 \%$ for C and $6.25 \%$ for D. Statistically, the predominance rates of $\mathrm{HBsAg}(+\mathrm{ve})$ donors were considerably different according to age groups (Table 2; Figures 3 and 4). Pragmatic predominance of anti HCV values $0.04 \%, 0.40 \% 0.30 \%$ $0.4 .34 \%$ for diverse age groups $\mathrm{A}, \mathrm{B}, \mathrm{C} \& \mathrm{D}$ respectively (Table 2 and Figure 4 ). These values show noteworthy difference among the different age groups.

\section{Discussion}

The focus of the current study is the predominance of HBsAg (+ve) obtained was $1.24 \%$. This is lower compared to the $8.0 \%$ predominance rate in I.V. drug users and $9.7 \%$ predominance in commercial sex workers reported by Bangladesh Medical Research Council Bulletin (BMRCB) published 1989. One reason for the high predominance identified the feasible insertion of proficient blood donors which have been demonstrated which have higher predominance rate compared to volunteer blood donors. Anti-HCV predominance was $0.16 \%$ observed through the study. Factors that may contribute to the wide discrepancy include ethnic mix of population, frequency of injection drug use and the proportion of the population that engages in high risk behavior. Injection drug use was mentioned to be the single most important risk factor for $\mathrm{HCV}$ infection. $\mathrm{HCV}$ infection is also proportionally 


\begin{tabular}{|c|c|c|c|c|c|c|}
\hline \multirow[b]{2}{*}{$\begin{array}{l}\text { Age } \\
\text { Group } \\
\text { (Years) }\end{array}$} & HBsAg & & & Anti-HCV & & \\
\hline & \begin{tabular}{c|} 
Pa- \\
tient's \\
Number
\end{tabular} & $\begin{array}{l}\text { Positive } \\
\text { Case }\end{array}$ & $\begin{array}{l}\text { Chi- } \\
\text { Square } \\
\text { Test }\end{array}$ & $\begin{array}{l}\text { Patient's } \\
\text { Number }\end{array}$ & $\begin{array}{l}\text { Positive } \\
\text { Case }\end{array}$ & $\begin{array}{l}\text { Chi- } \\
\text { Square } \\
\text { Test }\end{array}$ \\
\hline $18-28(A)$ & 1761 & $\begin{array}{c}11 \\
(0.62 \%)\end{array}$ & \multirow{4}{*}{$\begin{array}{c}<0.0001 \\
S \\
\text { According } \\
\text { to Age }\end{array}$} & 2166 & $1(0.046 \%)$ & \multirow{4}{*}{$\begin{array}{c}<0.0001 \\
S \\
\text { According } \\
\text { to Age }\end{array}$} \\
\hline 29-39(B) & 631 & $\begin{array}{c}17 \\
(2.69 \%)\end{array}$ & & 492 & $2(0.40 \%)$ & \\
\hline 40-50(C) & 592 & $\begin{array}{c}06 \\
(1.01 \%)\end{array}$ & & 329 & $1(0.30 \%)$ & \\
\hline $\begin{array}{c}\text { Above } \\
51(D)\end{array}$ & 64 & $\begin{array}{c}04 \\
(6.25 \%)\end{array}$ & & 23 & $1(4.34 \%)$ & \\
\hline
\end{tabular}

Significance(S) $=\mathrm{P}<0.05$

Table 2: Frequency of $\mathrm{HBsAg}(+\mathrm{ve})$ and anti-HCV among blood donors according to Age group.

associated with high risk sexual behavior, taking into accounts the number of sexual partners. Furthermore, patients who tested positive for HBsAg was not anymore screened for Anti-HCV for cost cutting purpose, hence excluding hepatitis $\mathrm{B}(+\mathrm{ve})$ who may have concomitant hepatitis C.

Several studies were also conducted in other countries on the predominance of Hepatitis in blood donors. In Egypt, the predominance of hepatitis B among blood donors was $39.4 \%$, while hepatitis C showed a value of $24.8 \%$ [11]. The values were higher compared with the values obtained in this study. A similar study was conducted in Indonesia with Hepatitis B predominance of $8.8 \%$ [12], and in Ghana, blood donor population showed that $15 \%$ were chronic carriers of Hepatitis B. In Bangladesh anti HCV reported a predominance of $2.4 \%$ in professional blood donors [13]. In the USA, a study among blood donors showed an HCV predominance of $0.4 \%$ [14] while in West Mexico, $0.8 \%$ of the blood donors were reported to be anti HCV positive [15]. A hospital based study in Lebanon showed that $0.4 \%$ [16] were anti HCV positive among blood donors may not be aware of their condition and therefore have the potential on this study.

The predominance of HBsAg (+ve) among healthy blood donors is apparently high. These results underlie the importance of screening programs in identifying blood borne pathogens which pose threat to potential recipients. Most developing countries including the Bangladesh are facing several threats to the safety of their blood supply. Screening for hepatitis viruses should be done most especially in high Predominance areas, since up to $20 \%$ of the collected blood might be unsafe. Both hepatitis $\mathrm{B}$ and $\mathrm{C}$ blood borne pathogen which could be transmitted by the parenteral route. Sometimes, infection results chronic asymptomatic carrier state for several years before the developments of symptoms. Hepatitis infected blood donors may not be conscious of their condition and therefore have the potential to pass on a disease to patients.

Follow up on blood donors who tested positive should also be done and if feasible to screened family members as they are at high risk for infection, due either to intra familial transmission or because they share risk factors for infection. Accurate identification and clinical management of both blood donors and family member would reduce the probability of transmission, preventing further dissemination in the community. Consciousnesses about blood safety have focused much attention on alternative blood transfusion strategies such as autologous blood, viral inactivation, and simulated blood substitutes.

On the basis of the HBsAg (+ve) carrier rate, the world can be divided in three regions as: high, medium and low endemicity. The major concern is about high endemicity countries, where the most

\section{Frequency of Age for HBsAg Screening}

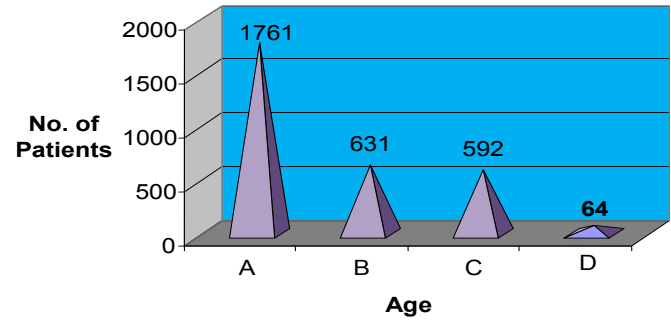

Abbreviations: $\mathrm{HBsAg}(+\mathrm{ve})$, hepatitis B surface antigen

Figure 3: Frequency of HBsAg according to Age group.

\section{Frequency of Age for Anti-HCV Screening}

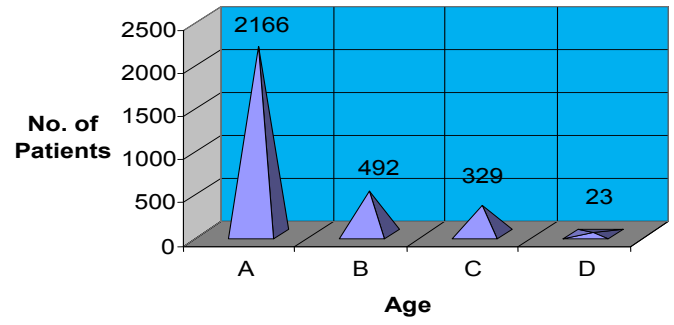

Abbreviations: Anti-HCV, hepatitis $\mathrm{C}$ virus antibody

Figure 4: Frequency of Anti-HCV according to Age group.

common route of infection remains vertical transmission from mother to child. Screening of all pregnant women and passive immunization with human hepatitis B immunoglobulin are not affordable for many developing countries. The infection rate can be abridged by modifying behavior, improving individual education, testing all blood donations, assuring asepsis in clinical practice and screening all pregnant women. However, availability of a safe and efficient vaccine and adoption of suitable immunization strategies are the most effective means to prevent HBsAg (+ve) infection and its consequences. The unsolved problem for poor countries, where the number of people currently infected is high, is the cost of the vaccine.

This work has attempted to provide information on the current risks of blood transfusion in Bangladesh among the healthy blood donors.

\section{Acknowledgement}

We are thankful to Anwer Khan Modern Medical College \& Hospital Ltd Dhaka, Bangladesh for their providing opportunity of sample collection and also to Primeasia University for its valuable help to carry our the research work.

\section{Authors Contributions}

All authors contributed equally to this work. All authors discuss the results and implications and commented on the manuscript at all stages.

\section{References}

1. Berenguer M, Wright $T$ (2002) Viral hepatitis. Sleisenger and Fordtran. GI and Liver Diseases, Philadelphia. WB Saunder 1278-1341.

2. Freeman AJ, Dore GJ, Law MG, Thorpe M, Von Overbeck J, et al. (2001) Estimating progression to cirrhosis in chronic hepatitis $\mathrm{C}$ virus infection. Hepatology 34: 809-816. 
Citation: Uddin MP, Azmal Morshed AM (2013) Predominance of HBsAg (+ve) and Anti-HCV Positivity among Blood Donors: Experience in a Private Hospital of Dhaka, Bangladesh. J Blood Disorders Transf 4: 154. doi: 10.4172/2155-9864.1000154

3. Allain JP, Candotti D, Soldan K, Sarkodie F, Phelps B, et al. (2003) The risk of hepatitis B virus infection by transfusion in Kumasi, Ghana. Blood 101: 2419-2425.

4. Cisneros-Castolo M, Hernández-Ruiz L, Ibarra-Robles IE, Fernández-Gárate RH, Escobedo-De La Peña J (2001) Prevalence of hepatitis B virus infection and related risk factors in a rural community of Mexico. Am J Trop Med Hyg 65: 759-763.

5. Global Burden Of Hepatitis C Working Group (2004) Global burden of disease (GBD) for hepatitis C. J Clin Pharmacol 44: 20-29.

6. Thorburn D, Dundas D, McCruden EA, Cameron SO, Goldberg DJ, et al (2001) A study of hepatitis C prevalence in healthcare workers in the West of Scotland. Gut 48: 116-120.

7. Mustafa M, Islam MN, Rahman M, Salauddin AK (1989) Prevalence of hepatitis $B$ surface antigen ( $\mathrm{HBsAg})$ among parenteral drug abusers at Dhaka. Bangladesh Med Res Counc Bull 15: 1-7.

8. Sattar H, Islam MN (1996) Hepatitis B virus markers among the prostitutes of Dhaka. Bangladesh Med Res Counc Bull 22: 8-11.

9. Gibney L, Saquib N, Metzger J, Choudhury P, Siddiqui M, et al. (2001) Human immunodeficiency virus, hepatitis B, C and D in Bangladesh's trucking industry: prevalence and risk factors. Int J Epidemiol 30: 878-884.

10. Barbara JA (1994) Viral hazards of transfusion: new developments. J Med Microbiol 40: 227-228.
11. Arthur RR, Hassan NF, Abdallah MY, el-Sharkawy MS, Saad MD, et al. (1997) Hepatitis $C$ antibody prevalence in blood donors in different governorates in Egypt. Trans R Soc Trop Med Hyg 91: 271-274.

12. Sulaiman HA, Julitasari, Sie A, Rustam M, Melani W, et al. (1995) Prevalence of hepatitis B and C viruses in healthy Indonesian blood donors. Trans R Soc Trop Med Hyg 89: 167-170.

13. Khan M, Husain M, Yano M, Hashizume K, Yousuf M, et al. (1993) Comparison of seroepidemiology of hepatitis $\mathrm{C}$ in blood donors between Bangladesh and Japan. Gastroenterol Jpn 28 Suppl 5: 28-31.

14. Glynn SA, Kleinman SH, Schreiber GB, Busch MP, Wright DJ, et al. (2000) Trends in incidence and prevalence of major transfusion-transmissible viral infections in US blood donors, 1991 to 1996. Retrovirus Epidemiology Donor Study (REDS) JAMA 284: 229-235.

15. Vivas-Arceo C, Benavides SA, De Jesús Trujillo J, Panduro A, Rivas-Estilla AM (2003) Hepatitis C virus: prevalence and routes of infection among blood donors of West Mexico. Hepatol Res 25: 115-123.

16. Tamim H, Irani-Hakime N, Aoun JP, Khoury S, Samaha H, et al. (2001) Seroprevalence of hepatitis $\mathrm{C}$ virus (HCV) infection among blood donors: a hospital-based study. Transfus Apher Sci 24: 29-35.
Citation: Uddin MP, Azmal Morshed AM (2013) Predominance of HBsAg $(+\mathrm{ve})$ and Anti-HCV Positivity among Blood Donors: Experience in a Private Hospital of Dhaka, Bangladesh. J Blood Disorders Transf 4: 154. doi: 10.4172/2155-9864.1000154 